\title{
Fiscal Policy and Growth: An Empirical Evaluation in CFA Franc Zone
}

\author{
Mondjeli Mwa Ndjokou ${ }^{1}$ \\ ${ }^{1}$ Laboratoire d'Analyse et de Recherche en Economie Appliquée (LAREA), Faculty of Economics and \\ Management, Cameroon \\ Correspondence: Mondjeli Mwa Ndjokou, Laboratoire d'Analyse et de Recherche en Economie Appliquée \\ (LAREA), Faculty of Economics and Management, University of Yaoundé II, Soa, Cameroon. E-mail: \\ motande@yahoo.fr
}

Received: March 30, 2013

Accepted: May 9, $2013 \quad$ Online Published: June 20, 2013

doi:10.5539/ibr.v6n7p131

URL: http://dx.doi.org/10.5539/ibr.v6n7p131

\begin{abstract}
This paper evaluates the link between fiscal policy and growth. For this purpose, we evaluate the influence of the level of public expenditures and revenues as well as the composition of the budget on economic growth. Relying on data provided by African Development Indicators, our sample is made of 9 countries of the CFA Franc Zone over the period 1990- 2010. Focusing on panel data techniques, our analysis leads to the following results: (i) public expenditures reduce significantly growth; (ii) an increase in revenues is associated with positive GDP per capita growth even though the relation is not statistically significant; (iii) the composition of the budget matter on economic growth process especially indirect taxes (which enhance GDP per capita growth) and wages and salaries (which harmful growth).
\end{abstract}

Keywords: Zone Franc, public expenditures, revenues, composition of budget

\section{Introduction}

Sub Saharan Africa (SSA) countries record since the 2000s positive growth rate. Over the period 2004-2008, African countries have recorded an average growth rate of $6.5 \%$. Between 2009 and 2011, the growth rate is still positive while decreasing: it is $2.8 \%, 5.3 \%$, and $5.1 \%$ respectively in 2009,2010 and 2011 . Their performances are higher in most cases than the world average. For example, the world economic records a growth rate of $-0.6 \%$ in 2009 and $3.9 \%$ in 2011. The growth trends offer more interesting statistics in some countries. Countries including Chad, Equatorial Guinea, Mali, Angola and Ethiopia achieved at least once double digits positive growth rate since 2000. Thus, CFA Franc Zone (FZC) countries are among those which face higher growth rate. Two comments can be made to the evolution of Franc Zone's performances. First, economic growth in FZC countries is not sustainable since it is partly driven by the export of raw materials and extractive industries. It is therefore highly dependent on global economic conditions. The impact of global economic crisis of 2008 is an illustration where the statistics point out a decrease in growth rates in most of these countries. In Equatorial Guinea for example, the growth rate falls from $11.29 \%$ in 2008 to $-5.44 \%$ in 2009 . Second, the growth rate of most FZC countries remains far from the $7 \%$ required for the achievement of the Millennium Development Goals. Therefore, the research of potential sources of a sustainable growth remains a major issue.

What drives economic growth? This key question has been widely documented both theoretically and empirically over the centuries since Smith (1776). Beginning with the Neoclassical Solow model through endogenous growth models, many factors are identified as potential sources of economic growth. Beside this debate, there is another on the relevance of State intervention in the economic sphere. The classical paradigm postulates the superiority of market mechanisms in the optimal allocation of resources and therefore advocate for a minimal State. On the contrary, Keynesian theory justifies the state intervention by the permanence of disequilibrium and inefficiency of markets (monopoles, externalities, incomplete market etc.). The implementation of appropriate policies can therefore permit to achieve the goals of Kaldor's Magic Square (1957). Regarding economic growth, the literature has identified various fiscal, monetary, trade, exchange rate, and financial policies indicators that are significantly correlated with long-run growth. Following Keynes (1936), Easterly and Rebelo (1993) asserts that fiscal policy is likely to be an important growth determinant. Fiscal policy is a short-run issue. It could therefore be used to mitigate short-run fluctuations of output and 
employment. For the neoclassical growth model of Solow (1956), this statement is questionable. Fiscal policy has no effect on the long-run growth rate. Public policy neoclassical growth models consign the role of fiscal policy to one determining the level of output rather than the long-run growth rate since the steady-state growth rate is driven by the exogenous factors of population growth and technological progress (Note 3). But, following endogenous growth models, fiscal policy can play a role in the growth process. The pioneering contributions are the theoretical papers of Barro (1990), Romer (1990), and Lucas (1988, 1990). Lucas (1988) argues that public investment in education increases the level of human capital and this can be seen as a main source of long-run economic growth (Note 4). Moreover, Barro (1990) mentions the importance of government expenditure in public infrastructure for economic growth; Romer (1990) stresses the relevance of research and development expenditure as determinant of growth. Since these pioneering contributions, several papers (Note 5) provide mechanisms by which fiscal variables can affect long-run growth and there is a still an ongoing debate (See for example Carrère \& de Melo, 2012; Ojede \& Yamarik, 2012).

This paper extends the debate and the purpose is to evaluate the link between fiscal policy and economic growth in FZC countries. The challenges of the study are threefold. Firstly, there is no study to our knowledge of the abundant literature addressing this question in developing countries which form a monetary union with fixed exchange rate. As it is well known and following Mundell's incompatibility triangle, when countries are in monetary union with fixed exchange rate, they lose the possibility to use monetary policy as regulatory instrument. Fiscal policy is therefore the main instrument. Moreover, there is a renewed interest in the literature of effects of fiscal policy on the economy since the 2000s. Secondly, as in many SSA countries, FZC countries still face serious difficulties implementing fiscal policy. They are characterized by a growing informal sector, a weak private sector due to lack of incentives, unfair income distribution and higher proportion of the population affected by extreme poverty, vulnerability to external shocks, political instability, governmental and institutions inefficiencies. Thirdly, the paper attempts to address many issues of fiscal policy in relation with growth. Fiscal policy is generally analyzed on the expenditure and the revenue side. On expenditure side, several fiscal policy instruments (Note 6) are known to exhibit long-run effects. On revenue side, fiscal variables which influence the growth process are direct taxes, indirect taxes and grants. Generally, these questions are treated separately by empirical research except the study of Kneller et al (1999). In this paper, we evaluate the incidence of public expenditure and revenue and their respective composition on growth.

The result of this study confirms that there is a strong link between public expenditure and growth. Also, the study finds a positive association between government's revenues and economic growth although the relation is not significant. The budget's composition is also detrimental for growth. In this regard, wages and salaries (indirect taxes) affect negatively (positively) and significantly the growth process.

The rest of the paper is structured as follows. In section 2, we figure out the channels by which fiscal policy can affect growth. Section 3 outlines the empirical analysis. Section 4 draws conclusions and policy recommendations.

\section{The Channels}

Since the 1960's, many studies have been looking at the relationship between fiscal policy and economy's growth rate. As mentioned earlier, the pioneer neoclassical model gives no role to fiscal policy variables in growth process. But, seminal work of Arrow and Kurz (1970) (Note 7) stress the existence of such a relation. They develop a model where consumers derive utility from private consumption as well as the public capital stock. Their model was in neoclassical tradition where public spending only affected economy's transitional growth rate. With introduction of endogenous growth models, fiscal policy becomes an important factor explaining the level of output and thus economic growth in any country. Therefore, a great number of studies explain theoretically and empirically the relation between fiscal policy and growth. The literature identifies many channels by which fiscal policy is transmitted into the economy. Without being exhaustive, we confine ourselves on influence of public spending, revenue and their components on growth.

The literature identifies three sources of public expenditure financing namely monetary financing, public debt and taxation. These different forms of financing are not neutral vis-à-vis economic growth. Nowadays, the possibility of monetary financing is reduced in most of the countries because of its negative effects on inflation. Public debt is another issue for government's authorities to finance their expenditures; but in this paper we focus mainly on taxation resources. The general point of view is that taxes are harmful for the economy's growth rate. Zagler and Dürnecker (2003), in a theoretical model, investigate on the relation between taxation and economic growth. According to the authors, two types of taxes exhibit a relation with the long run growth rate. The first one is taxation of labor and profits. Taxes on labor can affect economic growth through its impact on human 
capital. Thus, labor income taxation inhibits the accumulation of human capital when marginal benefits of schooling can be less than the marginal costs. The tax on profits also alters the growth rate of economy since it reduces amount of savings. The second type is taxation of capital and consumption. A capital income tax harms economic growth because of its negative effects on physical capital accumulation. The higher the capital income is, the higher the current consumption would be discouraging therefore accumulation of physical capital. Looking at the consumption taxation, effect on growth depends on how this tax is levied; if it's levied uniformly in all the products available to households, there is no impact. On contrary, if consumption taxation is not uniform, there is an impact depending on growth potential of firms producing the goods. The tax structure can also have important growth implications. Many studies on this point have been provided by Fiaschi (1999) and Kneller et al (1999). Several papers have attempted to identify the nature of relation between taxation and economic growth. Two main findings can be drawn from the existing literature. On one side, Uhlig and Yanagwa (1996), Mendoza et al (1997) mention the increasing relation between taxation and the fluctuations of output. On the other, Engen and Skinner (1996), Milesi-Feretti and Roubini, (1998) confirm the negative relationship between taxes and growth rate of the economy.

Regarding public spending, a great number of researchers study its effects on economic growth. Keynes (1936) was the first to figure out the relevance of public spending to mitigate disequilibrium faced by economy. Barro (1990) figures out how public spending can improve the growth process. But, to better analyze the role of public expenditures in growth process, it is useful to focus on composition of these expenditures. It is generally agreed that government consumption hampers economic growth since the higher taxes needed to finance the consumption expenditure reduce the incentive to invest. Government investment such as provision of infrastructure services is known to foster long-run growth (Note 8). A better distinction is the one given by Devarajan et al (1996) who divide public expenditure into productive and unproductive expenditures. Many fiscal indicators can be considered as productive expenditure such as public capital, public investment, public spending on health, education etc. The major unproductive expenditure category is social security expenditures. They may be of course some debate over the classification of expenditures as productive or non- productive. For example, while Summers and Heston (1988) classify defense and education as government consumption and hence unproductive, Barro (1991) models them as productive. Also, the general point of view is that productive expenditure is growth-enhancing while non-productive is not since it's purely consumptive. This statement is confirmed empirically Odedokun (1997), Aschauer (2000) and Bloom et al (2001) (Note 9). According to the authors, consumption expenditure is associated with upper per-capita real GDP growth and the relationship between capital component of public expenditure and per-capita growth is negative. Devarajan et al (1996) find opposite results. The composition of public outlays also matters in the growth process. For Gupta et al (2005), countries where spending is concentrated on wages tend to have lower growth, while those allocating higher shares to capital and nonwage goods and services enjoy faster output expansion. In the same line, Alesina and Perroti (1996) and Alesina and Ardagna (1998) find that budget composition matters in explaining different private sector responses to fiscal policy and hence the effects on growth.

Ultimately, the theoretical framework underlying empirical analysis carried out in this paper focuses on growth theory and its relation with fiscal policy. The latter can affect the former in short and long-run. Numerous channels through which the relationship exists are identified in the theory. If theory is reasonably clear, empirical evidence is not conclusive. The evaluation of some transmission channels of the relation between fiscal policy and growth is the main concern of the study. In fact, understanding the channel through which the fiscal policy affects growth can help to understand how to redirect public spending and revenue, and which component should be limited or promoted.

\section{Empirical Evaluation}

\subsection{Descriptive Approach}

Table 1 gives some descriptive statistics of the main variables of the study. It can be seen that economic growth rate is on average around $0.58 \%$ per capita per annum within the sample. This is partly justified by the poor economic performances during the decade 1990-2000. Among the fiscal variables, different components of the budget represent on average less than $10 \%$ of the GDP. As reported in table 1, indirect taxes have the higher rate ( $9.23 \%$ of GDP on average) while direct taxes amount on average for only $5.565 \%$ of the GDP. Regarding the proportion of taxes on GDP, statistics show that they are largely below the average in SSA countries where direct and indirect taxes are on average around $20 \%$ of GDP. Public capital expenditures represent on average $7.173 \%$ of GDP. This ratio is not consistent in order to have a sustainable growth. Concerning the two main components of budget that are expenditures and revenues, their proportion to GDP are respectively on average $22.18 \%$ and $18.59 \%$ which it is in line with the statistic in other SSA countries. 
Table 1. Descriptive statistics

\begin{tabular}{llll}
\hline Variables & observations & Mean & Standard deviation \\
\hline GDP growth per capita & 189 & 0.538 & 3.223 \\
Public expenditures & 189 & 22.934 & 6.343 \\
Revenues & 189 & 19.678 & 7.830 \\
Direct taxes & 189 & 5.565 & 6.259 \\
Indirect taxes & 189 & 9.493 & 3.516 \\
Wages and salaries & 189 & 5.971 & 2.410 \\
Public capital expenditures & 189 & 7.173 & 3.783 \\
\hline
\end{tabular}

Source: Authors 'calculations.

Note: The fiscal variables are in percentage of GDP.

Table 2 reports simple correlations between fiscal variables and economic growth. As reported in the table 2, some fiscal variables have a significant association with growth. For instance, higher public capital expenditures are associated with more favorable growth. Wages and salaries are negatively correlated with economic performance and this relationship is strong. The other fiscal variables have the expected sign although they are not significant. These preliminary findings are consistent with previous empirical evidence.

Table 2. Bivariate correlations (variables expressed as percentage of GDP)

\begin{tabular}{lll}
\hline variables & Per capita real GDP growth & observations \\
\hline Public expenditures & $-0.1134(0.1202)$ & 189 \\
Revenues & $0.0159(0.8276)$ & 189 \\
Direct taxes & $0.0615(0.4006)$ & 189 \\
Indirect taxes & $0.0586(0.4230)$ & 189 \\
Wages and salaries & $-0.4082(0.0000)^{* * *}$ & 189 \\
Public capital expenditures & $0.3230(0.0000)^{* * *}$ & 189 \\
\hline
\end{tabular}

Source: Authors' calculations.

Note: Bilateral correlations using annual data from 1990 to 2010 . * Significant at $10 \%$; **Significant at 5\%; ***Significant at $1 \%$.

\subsection{Econometric Method}

The relationship between fiscal policy and growth can be estimated by regressing the annual per capita GDP growth on a set of regressors, including fiscal variables and other control variables. Two specifications are used following Gupta et al (2005)'s paper. In the first model (model A), the fiscal variables are revenue and expenditure level captured as a share of GDP. The composition of revenue and expenditure are taken as fiscal variables in the second model (model B); this allow to address the question of which component of the budget mainly influence economic growth in FZC countries.

Model A: Revenue and expenditure level of the budget and economic growth.

$$
g_{t}=a+\sum_{l=1}^{k} b_{l} Y_{l t}+\sum_{h=1}^{q} b_{h} A F V_{h t}+\varepsilon_{t}
$$

where $g_{t}$ is the growth rate of GDP per capita at time $t ; Y_{t}$ is a vector of non-fiscal independent variables; and $A F V_{h t}$ is a vector of independent fiscal variables aimed at capturing the effect of revenue and expenditure level on growth. The fiscal variables in model A are taken as a share of GDP.

Model B: Composition of revenue and expenditure and economic growth.

$$
g_{t}=a+\sum_{l=1}^{k} b_{l} Y_{l t}+\sum_{h=1}^{q} b_{h} B F V_{h t}+\varepsilon_{t}
$$

where $g_{t}$ is the growth rate of GDP per capita at time $t ; Y_{t}$ is a vector of non-fiscal independent variables; and $B F V_{h t}$ is a vector of independent fiscal variables aimed at capturing the effect of the composition of revenue and expenditure. These variables are measured in percentage of GDP. The revenue variables include: direct taxes and indirect taxes. The expenditure categories include: public sector wages salaries and public capital expenditures. 


\subsection{Data and Sources}

Recall that the aim of this paper is to identify the channels by which fiscal policy affects growth. Two aspects of fiscal policy are examined in relation to their impact on growth. The first one considers the level of government budget while the second takes into account the composition of budget. The level of government budget identifies on one side the revenue captured by total revenues including grants. On the other side, we have the expenditures measured by total expenditures and net lending. The composition of budget comprises direct taxes, indirect taxes, public sector wages and salaries, public capital expenditures. Growth is measured by GDP growth per capita. It would have been useful to add more fiscal variables in the analysis notably variables that captures the expenditure composition of the budget; but due to data availability in all the countries of sample we limit ourselves to the variables listed. However, the chosen variables can be classified into one of the following categories: distortionary or non-distortionary taxation and productive or non-productive expenditures. According to Barro (1990), direct taxes are considered as distortionary taxation while indirect taxes are non-distortionary (Note 10). Public capital expenditures are known as productive. According to Kneller et al (1999), wages and salaries can be classified into productive expenditures whereas Devarajan et al (1996) consider them as unproductive. But in our study, we consider that wages and salaries are non productive because of the weakness of the public sector in FZC notably in terms of efficiency.

Non-fiscal variables are taken as control variables in the different models. The choice of control variables is crucial because the introduction of particular control variable can wipe out the bivariate relationship between indicators of fiscal policy and growth (Easterly \& Rebelo, 1993). Thus, it is necessary to consider which information to include in growth regression as control variables. Sala-i-Martin (1997) has identified 60 variables to be significant in at least one growth regression. In a more rigorous analysis, Levine and Renelt (1992) show that average investment share to GDP, initial log of GDP per capita, initial human capital and average growth rate of the population are correlated with growth. In our study, four control variables are included in different models. The first one (private investment) captures the effect of private sector on growth. Private investment is captured by private gross fixed capital formation as percentage of GDP. The influence of external sector activity is also important; in this vein openness is a variable found to be significant in many cross-country growth regressions. Therefore, openness of the economy is the second control variable and it is measured as the sum of export and import of goods and services as a share of GDP. The third variable is labor force taken as a growth rate. Since it's agreed that human capital contributes to enhance growth, we also control the level of initial primary enrollment measured by gross primary school enrollment ratio.

Our data set covers 9 countries namely Benin, Burkina Faso, Cameroon, Congo, Gabon, Ivory Coast, Mali, Niger and Senegal for the period 1990- 2010. The data are annual and are obtained from African Development Indicators database. Due to the short sample period, we cannot follow the standard practice of taking 5 year averages to remove the effects of business cycle; but following Gupta et al (2005), business cycle may be weaker in low-income countries due to absence of automatic stabilizers. Moreover, Folster and Henrekson (1997) find that the pattern of the relationship is similar even though there is a change in the significativity level when annual data are used rather than three, five and ten years interval.

\subsection{Results and Discussions}

The first analysis is to test for stationary properties of the series. In our study we run the Im, Pesaran and Shin (IPS) unit root test to determine whether the variables are stationary or not. The IPS test is the most often used in practice because it is simple and easy to use. However, it's more powerful than Levin and Lin test. The IPS test is based on the well-known Dickey-Fuller procedure. The IPS test combine information from time series dimension with that from cross section dimension. Its specification include time trend. The results show that all the variables are stationary in level.

After, we run a likelihood ratio test to see whether there is heterogeneity in the data especially if it's possible to detect individual effects. For this purpose, we estimate a panel data with fixed effects. The statistic of Fisher test gives the value 3.49 with a probability of 0.0009 and 2.82 with a probability of 0.0058 respectively for model A and model B suggesting that the null hypothesis of the test is rejected. Therefore, we can estimate a panel data by specifying individual effects. The problem is now to choose between fixed effects models and random effects models by running the Hausman test. The Hausman test favors the specification of a fixed effect models.

Another problem that is encountered in panel data estimation is the presence of heteroskedasticity and autocorrelation. There are several cases where heteroskedasticity can arise. Most often it appears in a form where error term is correlated with one of independent variables or with the dependent variable. We run conventional test and detect that variance of errors are not constant and there is a serial correlation in the residual. To address 
this, we run a general least square (GLS) estimation. The following table summarizes the main findings.

Table 3. Expenditures, revenues, budget composition and growth in CFA Zone: fixed effects

\begin{tabular}{|c|c|c|}
\hline Variables & Model A & Model B \\
\hline \multirow[t]{3}{*}{ Public expenditures } & $-0.183 * * *$ & - \\
\hline & 0.000 & \\
\hline & $(-3.99)$ & \\
\hline \multirow[t]{3}{*}{ Revenues } & 0.023 & - \\
\hline & 0.592 & \\
\hline & $(0.54)$ & \\
\hline \multirow[t]{3}{*}{ Direct taxes } & - & 0.042 \\
\hline & & 0.370 \\
\hline & & $(0.90)$ \\
\hline \multirow[t]{3}{*}{ Indirect taxes } & - & $0.144 *$ \\
\hline & & 0.051 \\
\hline & & $(1.95)$ \\
\hline \multirow[t]{3}{*}{ Wages and salaries } & - & $-0.636 * * *$ \\
\hline & & 0.000 \\
\hline & & $(-6.16)$ \\
\hline \multirow[t]{3}{*}{ Public capital expenditures } & - & 0.069 \\
\hline & & 0.440 \\
\hline & & $(0.77)$ \\
\hline \multirow[t]{3}{*}{ Labor force } & 0.037 & 0.051 \\
\hline & 0.426 & 0.240 \\
\hline & $(0.80)$ & $(1.17)$ \\
\hline \multirow[t]{3}{*}{ Primary school enrolment } & $-0.025 * * *$ & -0.0019 \\
\hline & 0.006 & 0.847 \\
\hline & $(-2.72)$ & $(-0.19)$ \\
\hline \multirow[t]{3}{*}{ Private investment } & $0.225 * * *$ & 0.084 \\
\hline & 0.000 & 0.120 \\
\hline & $(4.80)$ & $(1.55)$ \\
\hline \multirow[t]{3}{*}{ Openness of the economy } & 0.009 & -0.0022 \\
\hline & 0.383 & 0.849 \\
\hline & $(0.87)$ & $(-0.19)$ \\
\hline \multirow[t]{3}{*}{ Constant } & 0.003 & -1.056 \\
\hline & 0.998 & 0.510 \\
\hline & $(0.00)$ & $(-0.66)$ \\
\hline Number of observations: & 189 & 189 \\
\hline Number of groups: & 9 & 9 \\
\hline Number of time period: & 21 & 21 \\
\hline Wald chi2: & 30.49 & 70.07 \\
\hline Prob > chi2: & 0.0000 & 0.0000 \\
\hline
\end{tabular}

Note: * Significant at $10 \% ; * *$ Significant at $5 \% ; * * *$ Significant at $1 \%$.

Dependent variable: GDP growth per capita; all the explanatory variables are measured as percentage of GDP except for Labor force (percentage of total population) and primary school enrolment. T-student is given in parentheses.

As reported in table 3 (model A), the growth is significantly affected by public expenditures, primary school enrolment and private investment. It's well documented that private sector play key role in the growth process. Concerning primary school enrolment, it's relation with growth is negative. Gupta and al (2005) also find that there is a negative and significant relation between primary school enrolment and GDP growth. Focusing on fiscal variables, we find an overwhelmingly strong negative relation between public spending and GDP per capita growth. The rationale of the result is that in developing countries, most governments do not focus on more productive items of budget. This result is the same as Barro (1997) and Folster and Henrekson (1997) which find a significant negative relationship between government spending and growth. But the magnitude of this relationship is weak. An increase of $1 \%$ of public spending decreases economic growth by $0.183 \%$. Devarajan et 
al (1996) find an opposite result; the effect of total government expenditure on per-capita growth is positive but statistically insignificant.

However, the study highlights a positive association between revenues and growth in CFA zone countries as suggest by theory and empirical studies although Afonso and Furceri (2008) find a negative relationship. But in our study, the relation is not significant and the value of parameter is even very small. We can therefore conclude that FZC countries do not mobilize enough revenues that can boost economic growth. This conclusion is confirmed by the estimation of model $\mathrm{B}$ which results are reported in table 3 . We observe that direct taxes have a positive and non-significant effect on growth even when we remove indirect taxes from the regression. This result raises the following comments. First, FZC countries can be considered as being in the increasing part of the Laffer's curve where taxes are growth enhancing. The increase in tax rates increases the amount of revenues of government which would finally promote growth. Second, the level of taxation is far from the optimal point since the contribution of direct taxes on growth is not significative. Otherwise, international comparisons show that tax burden in Less Developing countries (LDCs) is generally about half of the one in industrialized countries.

The other budget variables have also the expected sign. Wages and salaries influence negatively and significantly the growth; its estimated coefficient is 0.636. Gupta et al (2005) obtains similar result in low income countries. Wages and salaries are taken as government consumption and in general the government consumption is considered to hamper economic growth; although it seems obvious that certain categories of government consumption are expected to support growth such as infrastructure, education, and health expenditures. The second variable that significantly affects growth is indirect taxes as in Kneller et al (1999)'s paper. The estimate suggests that an increase of $1 \%$ percent indirect taxes raises growth by $0.144 \%$. The rationale behind this result is that indirect taxes like consumption taxes don't affect investment decision and reduce returns to investment and therefore can be growth-enhancing. On the contrary, as consumption of good and services is increasing, the amount of indirect taxes increases and can therefore affect growth. The study of Afonso and Fuerceri (2008) leads to a reverse result; an increase of one percentage point in indirect taxes ratio lowers growth by $0.30(0.40)$ percentage points for the OECD (EU) countries.

Although public capital expenditures and private investment are positively associated with GDP, their respective coefficients are not significant. According to Sala-i-Martin (1997) government investment appears to affect growth in a significant way especially in developing countries. But the result of our study is somewhat surprising for private investment notably since it's known as affecting growth significantly like in the estimation of model A. Such a result may come from the inclusion of private investment and public capital expenditure in the same growth equation. In fact, when we run a regression of model B without one of the two variables, the other became significative and has the expected sign.

\subsection{Robustness Analysis}

In this section we test the robustness of the above results. The estimation of models A and B assume that all of the right-hand side variables are exogenously determined. For example, Keynesian propositions treat public expenditures as an exogenous factor. But there is a possibility of simultaneity between fiscal variables and growth or reverse causality. As Earsterly and Rebelo (1993) and Hsieh and Lai (1994) discuss, the most likely sources of simultaneity in the regression are business cycle effects and Wagner's law. The Wagner's law expresses the tendency of government expenditure to be higher at higher levels of per capita GDP. This implies that fiscal variables like public expenditure can be treated as an outcome, or an endogenous factor rather than a cause of GDP growth. In fact, the ratio of government spending to GDP is likely to increase if the nominal expenditure is fixed as the economic growth slows down. Thus, estimation techniques that do not take into account this endogeneity will yield biased and inconsistent parameter estimates.

GMM and instrumental variables are methods addressing concerns about endogeneity. Since the GMM method is not applicable in our study, we estimate the previous models using instrumental variables methods. But the selection of instruments is a difficult task. Our choice follow Folster and Henrekson (1997) and Kneller et al (1999) papers and use the first difference of fiscal variables as instruments. Table 4 reports the result of regression with instrumental variables. Comparing the instrumental variables estimation with those in table 3 , it is clear that the fiscal effects identified earlier are not simply the result of endogeneity. Coefficients sign are unchanged and the magnitude of the variables is quite similar. Accounting for the endogeneity of fiscal variables does not improve the robustness of result as in the baseline regression. 
Table 4. Expenditures, revenues, budget composition and growth in CFA Zone: estimation by instrumental variables

\begin{tabular}{|c|c|c|}
\hline Variables & Model A & Model B \\
\hline \multirow[t]{3}{*}{ Public expenditures } & $-0.181 * *$ & \\
\hline & 0.002 & \\
\hline & $(-3.07)$ & \\
\hline \multirow[t]{3}{*}{ Revenues } & 0.045 & \\
\hline & 0.325 & \\
\hline & $(0.98)$ & \\
\hline \multirow[t]{3}{*}{ Direct taxes } & & -0.076 \\
\hline & & 0.375 \\
\hline & & $(-0.89)$ \\
\hline \multirow[t]{3}{*}{ Indirect taxes } & & $0.408^{* *}$ \\
\hline & & 0.013 \\
\hline & & $(2.49)$ \\
\hline \multirow[t]{3}{*}{ Wages and salaries } & & $-0.903 * * *$ \\
\hline & & 0.000 \\
\hline & & $(-5.41)$ \\
\hline \multirow[t]{3}{*}{ Public capital expenditures } & & -0.050 \\
\hline & & 0.689 \\
\hline & & $(-0.40)$ \\
\hline \multirow[t]{3}{*}{ Labor force } & -0.056 & -0.090 \\
\hline & 0.802 & 0.673 \\
\hline & $(-0.25)$ & $(-0.42)$ \\
\hline \multirow[t]{3}{*}{ Primary school enrolment } & 0.013 & 0.005 \\
\hline & 0.376 & 0.743 \\
\hline & $(0.89)$ & $(0.33)$ \\
\hline \multirow[t]{3}{*}{ Private investment } & 0.096 & 0.048 \\
\hline & 0.170 & 0.480 \\
\hline & $(1.37)$ & $(0.71)$ \\
\hline \multirow[t]{3}{*}{ Openness of the economy } & 0.036 & -0.039 \\
\hline & 0.145 & 0.174 \\
\hline & $(1.46)$ & $(-1.36)$ \\
\hline \multirow[t]{3}{*}{ Constant } & 0.727 & 7.543 \\
\hline & 0.933 & 0.382 \\
\hline & $(0.08)$ & $(0.87)$ \\
\hline Number of observations: & 189 & 189 \\
\hline Number of groups: & 9 & 9 \\
\hline Number of time period: & 21 & 21 \\
\hline Wald chi2: & 34.94 & 62.06 \\
\hline Prob > chi2: & 0.0000 & 0.0000 \\
\hline
\end{tabular}

Notes: * Significant at $10 \% ; *$ Significant at $5 \% ; * * *$ Significant at $1 \%$.

Dependent variable: GDP growth per capita; all the explanatory variables are measured as percentage of GDP except for Labor force (percentage of total population) and primary school enrolment. T-student are given in parentheses.

\section{Conclusions and Policy Recommendations}

Stylized facts, theory and empirical studies clearly point out that there is a relation between fiscal variables and economic growth. This relation depends on the level as well as the composition of government revenues and public expenditures. The aim of our paper was to evaluate the link between fiscal policy and economic growth. We have attempted to test this relationship using a data set for 9 FZC countries over the period 1990-2010. Our methodology focuses on panel data analysis when we use general least square (GLS) technique to account for heteroskedasticity and autocorrelation. To overcome the possibility of reverse causality between fiscal variables and growth or the problem of endogeneity, we estimate our empirical models by instrumental variables methods.

Consistent with previous findings in the literature, results point to a significant relationship between some fiscal variables and growth. Public expenditures for instance affect negatively and in significant manner the per capita 
growth rate. An increase of $1 \%$ of public spending decreases economic growth by $0.183 \%$. This implies that a reduction in public expenditure could boost per capita growth. However, it is not the level of public expenditures in the context of FZC countries which is problematic but its misallocation. The composition of public expenditure also matter in the economic growth process. Wages and salaries distort significantly growth. The value of the parameter is 0.636 and it is significant at $1 \%$ level. Wages and salaries can be considered as unproductive expenditures in FZC countries. Thus reductions in the public sector wage bill are not harmful for growth for the sample as a whole. However, there is a positive but not significant association between public capital expenditure and growth; there is therefore a need to reallocate resources to more productive items. On the revenue side, the study finds that fiscal variables have the expected sign but are not statistically significant except for indirect taxes. According to our results, indirect taxes are key factor affecting growth in FZC countries. A one percent increase of indirect taxes could raise growth by $0.144 \%$. This highlights the fact that the level of taxation is still low. The positive and not significant relation between direct taxes and growth could be viewed as the confirmation of this intuition. Governments authorities of the sample set still have a flexibility to increase the amount of direct taxes. Finally, accounting for endogeneity issue does not improve the analysis. The fiscal variables- economic growth nexus does not significantly change the previous results.

\section{References}

Afonso, A., \& Furceri, D. (2008). Governement size composition, volatility and economic growth. European Central Bank Working Paper 849.

Alesina, A., \& Ardagna, S. (1998). Tales of fiscal adjustment. Economic Policy: a European Forum, 27, 487-546. http://dx.doi.org/10.1111/1468-0327.00039

Alesina, A., \& Perotti, R. (1996). Fiscal adjustments in OECD countries: composition and macroeconomic effects. IMF Working Paper 70.

Aschauer, D. A. (2000). Do states optimize? Public capital and economic growth. Annals of Regional Science, 34, 343-363. http://dx.doi.org/10.1007/s001689900016

Barro, R. J. (1990). Government spending in a simple model of endogenous growth. Journal of Political Economy, 98(1), 103-117. http://dx.doi.org/10.1086/261726

Barro, R. J. (1997). Determinants of economic growth: A Cross-Country Empirical Study. Cambridge, MA: MIT Press.

Bloom, D. E., Canning, D., \& Sevilla, J. (2001). The effect of health on economic growth: theory and evidence. National Bureau of Economic Research, Working Paper 8587. National Bureau of Economic Research, Cambridge, MA.

Carrère, C., \& De Melo, J. (2012). Fiscal spending and economic growth: some stylized facts. World Development, 40(9), 1750-1761. http://dx.doi.org/10.1016/j.worlddev.2012.04.011

Devarajan, S., Swaroop, V., \& Zou, H. (1996). The composition of public expenditure and economic growth. Journal of Monetary Economics, 37, 313-344.

Easterly, W., \& Rebelo, S. (1993). Fiscal policy and economic growth: an empirical investigation. NBER Working Paper 4499. National Bureau of Economic Research, Cambridge, MA.

Engen, E. M., \& Skinner, J. (1996). Taxation and economic growth. NBER Working Paper 5826.

Fatás, A. (2002). The effects of business cycles on growth. In Loayza, N., \& Soto, R. (Eds.), Economic Growth: Sources, Trends and Cycles. Central Bank of Chile.

Fiaschi, D. (1999). Growth and inequality in an endogenous fiscal policy model with taxes on labour and capital. European Journal of Political Economy, 15, 727-746. http://dx.doi.org/10.1016/S0176-2680(99)00038-5

Folster, S., \& Henrekson, M. (1997). Growth and the public sector: a critique of the critics. IUI Working Paper Series, No. 492.

Gupta, S., Clements, B., Baldacci, E., \& Mulas-Granados, C. (2005). Fiscal policy, expenditure consumption and growth in low-income countries. Journal of International Money and Finance, 24, 441-463. http://dx.doi.org/10.1016/j.jimonfin.2005.01.004

Hsieh, E., \& Lai, K. (1994). Government spending and economic growth: the G7 experience. Applied Economics, 26(5), 535-542. http://dx.doi.org/10.1080/00036849400000022

Jones, L. E., Manuelli, R. E., \& Rossi, P. E. (1993). Optimal taxation in models of endogenous growth. Journal 
of Political Economy, 101, 485-517. http://dx.doi.org/10.1086/261884

Kneller, R., Bleaney, M., \& Gemmell, N. (1999). Fiscal policy and growth: evidence from OECD countries. Journal of Public Economics, 74, 171-190. http://dx.doi.org/10.1016/S0047-2727(99)00022-5

Levine, R., \& Renelt, D. (1992). A sensitivity analysis of cross-country growth regressions. American Economic Review, 82(5), 942-963.

Lucas, R. (1988). On the mechanism of economic development. Journal of Monetary Economics, 22, 3-42. http://dx.doi.org/10.1016/0304-3932(88)90168-7

Lucas, R. (1990). Supply-side economics: an analytical review. Oxford Economic Papers, 42(2), 293-316.

Mendoza, E., Milesi-Ferretti, G., \& Asea, P. (1997). On the effectiveness of tax policy in altering long-run growth: Harberger's superneutrality conjecture. Journal of Public Economics, 66(1), 99-126. http://dx.doi.org/10.1016/S0047-2727(97)00011-X

Milesi-Ferretti, G. M., \& Roubini, N. (1998). Growth effects of income and consumption taxes. Journal of Money, Credit and Banking, 30(4). http://dx.doi.org/10.2307/2601126

Odedokun, M. O. (1997). Relative effects of public versus private investment spending on economic efficiency and growth in developing countries. Applied Economics, 29, 1325-1336. http://dx.doi.org/10.1080/00036849700000023

Ojede, A., \& Yamarik, S. (2012). Tax policy and state economic growth: the long-run and the short-run of it. Economic Letters, 116, 161-165. http://dx.doi.org/10.1016/j.econlet.2012.02.023

Perotti, R. (1999). Fiscal policy in good times and bad. Quarterly Journal of Economics, 114(4), 1399-1436. http://dx.doi.org/10.1162/003355399556304

Romer, P. (1990). Endogenous technological change. Journal of Political Economy, 98(5), 71-102. http://dx.doi.org/10.1086/261725

Sala-i-Martin, X. (1997). I just ran two million regressions. American Economic Review, 87(2), 178-183.

Solow, R. M. (1956). A contribution to the theory of economic growth. Quarterly Journal of Economics, 71(1), 65-94. http://dx.doi.org/10.2307/1884513

Stokey, N. L., \& Rebelo, S. (1995). Growth effects of flat-rate taxes. Journal of Political Economy, 103, 519-550. http://dx.doi.org/10.1086/261993

Summers, R., \& Heston, A. (1988). A new set of international comparisons of real product and price levels: estimates for 130 countries. Review of income and Wealth, 34, 1-25. http://dx.doi.org/10.1111/j.1475-4991.1988.tb00558.x

Swan, T. W. (1956). Economic growth and capital accumulation. Economic Record, 32(3), 334-361. http://dx.doi.org/10.1111/j.1475-4932.1956.tb00434.x

Uhlig, H., \& Yanagawa, N. (1996). Increasing the capital income tax may lead to faster growth. European Economic Review, 40, 1521-1540. http://dx.doi.org/10.1016/0014-2921(96)00032-3

Zagler, M., \& Durnecker, G. (2003). Fiscal policy and economic growth. Journal of Economic Surveys, 17(3), 397-418. http://dx.doi.org/10.1111/1467-6419.00199

\section{Notes}

Note 1. CFA Franc Zone is a monetary area with CFA as common currency. This area includes: Cameroon, Gabon, Equatorial Guinea, Central Africa Republic, Chad, Republic of Congo, Ivory- Coast, Benin, Burkina Faso, Mali, Senegal, Niger, Bissau- Guinea and Togo.

Note 2. I acknowledge the comments of Zamo Akono Christian and comments from the anonymous members of LAREA network.

Note 3. Even if the government could influence the rate of population growth, for example by reducing infant mortality or encouraging child-bearing, this would not affect the long-run growth rate of per capita income (Kneller et al., 1999).

Note 4. If the returns to scale do not decline over time due to non-decreasing returns to scale in reproducible factors of production.

Note 5. Jones et al. (1993); Stokey and Rebelo, (1995); Mendoza et al., (1997). 
Note 6. Transfers, subsidies, government consumption and investment, interest payments on government debt and public sector wages and salaries.

Note 7. Cited by Devarajan et al (1996).

Note 8. It's possible to have certain categories of government expenditures such education, infrastructure and health expenditure which promote growth. On the contrary, not well targeted investment projects can contribute to reduce a point of growth.

Note 9. For example, Aschauer (2000) discusses in detail the impact of public capital on economic growth. Odedokun (1997) finds that public infrastructure investment promotes growth by facilitating private investment. According to Bloom et al (2001), health has a positive and statistically significant effect on growth.

Note 10. Direct taxes include for example income and property taxes and indirect taxes are consumption taxes.

\section{Copyrights}

Copyright for this article is retained by the author(s), with first publication rights granted to the journal.

This is an open-access article distributed under the terms and conditions of the Creative Commons Attribution license (http://creativecommons.org/licenses/by/3.0/). 